\title{
Efektivitas Pelatihan Metode Penelitian Tindakan Kelas Bagi Guru SD di Kecamatan Padang Timur Kota Padang
}

\author{
Nellitawati ${ }^{1} \&$ Aswardi $^{2}$ \\ ${ }^{12}$ Universitas Negeri Padang \\ *Corresponding author, e-mail: nellitawati@gmail.com
}

\begin{abstract}
This training aims to help teachers, especially elementary school teachers in conducting PTK, for the improvement of learning in the future. In detail, the goal to be achieved in the first year is the teacher understands the method of classroom action research. Teachers are able to draft the PTK design and implement the PTK. Which will then acquire the copyright and publication of the manuscript on International activities. activities. In second proceed to process of designing, developing models and creating modules for building self-integrity programs and reducing student violence. Training activities of PTK methods for elementary school teachers are conducted in UPTD Padang Timur. Before the question and answer is done, first the resource person presents the material that has been agreed upon. Then given the opportunity to participants to do question and answer and provide exercise in order to stabilize the material. The training of PTK method is done by presenting the material / theory about PTK method and followed by the drafting exercise of PTK under the guidance of the Implementation Team.
\end{abstract}

Keywords: Training, method of classroom action research
Received October 29, 2017; Revised November 22, 2017; Accepted December 25, 2017; Published Online January, 2018

Conflict of Interest Disclosures: The authors declare that they have no significant competing financial, professional or personal interests that might have influenced the performance or presentation of the work described in this manuscript.

(ब) This is an open access article distributed under the Creative Commons 4.0
Attribution License, which permits unrestricted use, distribution, and reproduction in any medium, provided the original work is properly cited. C2017 by author

How to Cite: Nellitawati, N., \& Aswardi, A. (2017). Efektivitas Pelatihan Metode Penelitian Tindakan Kelas Bagi Guru SD di Kecamatan Padang Timur Kota Padang. Jurnal Aplikasi IPTEK Indonesia, 1(1), 1-5. DOI: 10.24036/4.112

\section{Pendahuluan}

Sertifikasi saat ini merupakan suatu hal yang menarik untuk dibicarakan terutama dikalangan guru. Dimana-mana kita dengar guru-guru sibuk mempersoalkan sertifikasi. Sebagian guru harap-harap cemas menunggu panggilan untuk menyiapkan fortofolio, sebagian lagi resah dengan hasil penilaian fortofolionya yang belum jelas, ada juga yang cemas karena tidak dipanggil untuk mengikuti diklat, dan yang lainnya, resah menunggu hasil setelah mengikuti diklat. Semua ini dapat dijadikan indikasi tingginya keinginan, harapan dan semangat untuk memperoleh sertifikat profesi dari lembaga terkait.

Sertifikat profesi merupakan pengakuan LPTK yang telah ditentukan atas kompetensi yang dimiliki guru. Jika guru sudah memiliki sertifikat profesi ini, berarti secara formal pemerintah mengakui eksistensi kompetensi yang dimiliki guru. Sertifikat tersebut dijadikan salah satu syarat untuk menaikkan penghasilan guru dalam jabatannya sebagai guru. Hal ini membakar motivasi guru untuk mempersiapkan bahanbahan/bukti fisik kompetensi yang dimilikinya selengkap mungkin, agar mereka memperoleh nilai sesuai dengan yang dipersyaratkan lembaga. Untuk peningkatan karakter optimal siswa (Ifdil, I. 2010)

Salah satu bahan/bukti fisik yang dapat dimasukkan guru sebagai bahan penilaian adalah karya ilmiah. Jika guru mampu menyajikan sebagian bahan fortofolionya dalam bentuk karya ilmiah, maka besar kemungkinan batas penilaian minimal dapat dicapai oleh guru. Namun kenyataannya hanya sebagian kecil saja guru yang mampu menunjukkan kompetensinya melalui karya ilmiah. Hal ini dapat dijadikan satu indikasi bahwa guru masih minim sekali dalam menulis karya ilmiah. Barangkali hal ini dapat disebabkan beberapa faktor, seperti kurangnya waktu bagi guru untuk menulis karya ilmiah, kemampuan guru dalam menulis karya ilmiah masih kurang, dan motivasi berprestasi guru melalui karya ilmiah juga kelihatannya 
sangat kurang. Selain untuk memenuhi bahan sertifikasi dan naik pangkat, pengetahuan dan keterampilan melakukan penelitian tindakan kelas juga seharusnya sudah merupakan kebutuhan bagi guru. Dikatakan demikian karena melalui PTK guru dapat memperbaiki strategi pembelajaran yang dilakukan sehingga pembelajaran yang dilakukan lebih menyenangkan dan efektif.

Sebagian guru terkesan menunjukkan keinginan untuk melakukan PTK, namun terkendala dengan kemampuan yang dimiliki. Hal ini dapat dilihat dari ambisi mereka untuk bertanya, minta dibimbing, bahkan ada yang ingin bersama- sama melakukan PTK di sekolah mereka masing-masing. Namun keinginan tersebut belum pernah terealisasi, karena menurut guru belum memiliki pengetahuan dan keterampilan dalam melakukan PTK.Salah satu usaha yang mungkin dilakukan untuk membantu guru mengembangkan profesinya melalui karya ilmiah adalah melaksanakan pelatihan Penelitian Tindakan Kelas (PTK) bagi guruguru khususnya guru SD di Padang Timur.

Berdasarkan analisis situasi didukung berbagai teori dapat diidentifikasi permasalahan prioritas yang dihadapi adalah berkaitan dengan pelaksanaan rendahnya kemampuan guru dalam melakukan penelitian tindakan kelas bagi. Idealnya guru perlu selalu mencoba untuk mengubah dan mengembangkan serta meningkatkan gaya mengajarnya agar ia mampu melahirkan model pembelajaran yang sesuai dengan tuntutan kelasnya. Bila guru melakukan PTK di kelasnya berarti ia sudah melakukan proses inovasi pembelajaran. Fenomena menunjukkan bahwa kemampuan guru melakukan PTK terkesan masih kurang. Hal ini ditandai dengan belum pernahnya guru melakukan PTK, bahkan sebahagian guru menganggap PTK ini suatu hal yang baru. Kondisi ini jika dibiarkan akan berdampak pada mutu guru, yang jika berkelanjutan mempengaruhi proses pembelajarann dan mutu pendidikan nasional secara luas.

\section{Metodologi}

Metode yang digunakan dalam kegiatan pelatihan kali ini adalah ceramah, tanya jawab dan latihan. Sebelum tanya jawab dilaksanakan, terlebih para nara sumber menyajikan materi yang telah disepakati bersama. Kemudian diberi kesempatan kepada peserta untuk melakukan tanya jawab dengan para peserta serta memberikan latihan dalam rangka pemantapan materi. Pelatihan metode PTK dilakukan dengan cara menyajikan materi/teori tentang metode PTK dan dilanjutkan dengan latihan menyusun rancangan PTK di bawah bimbingan Tim Pelaksana.

\section{Hasil}

Kegiatan pelatihan PTK kepada guru SD di Padang Timur dinilai berhasil dilihat dari antusias guru mengikuti pelatihan dan intensitas peserta tersebut menghubungi narasumber diluar jadwal pelatihan untuk berdiskusi mengenai PTK yang dilakukannya disekolah. Hasil yang dicapai setelah melakukan pelatihan PTK kepada guru SD di Padang Timur adalah guru sudah mulai memahami metode penelitian tindakan kelas, guru mampu menyusun rancangan PTK, guru mampu melaksanakan PTK. Peserta juga mampu menemukan alternative lain, kemudian dicobakan, dan selanjutnya di evaluasi apakah tindakan-tindakan alternatif itu dapat digunakan untuk memecahkan persoalan pembelajaran yang sedang dihadapi oleh guru.

Setelah mengikuti kegiatan pelatihan PTK peserta telah mendapatkan wawasan, pengetahuan, pemahaman dan ketrampilan dalam menunjang penyelenggaraan tugas sebagai guru di sekolah, kegiatan ini memberikan semangat kembali kepada para guru untuk lebih giat lagi, bahkan harapan ini dikemukakan langung oleh perwakilan dari peserta agar kegiatan serupa lebih sering untuk dilaksanakan.

\section{Pembahasan}

\section{Pengertian Penelitian Tindakan Kelas}

Menurut Suharsimi Arikunto dkk (2006) mengemukakan penelitian tindakan Kelas merupakan sesuatu pencermatan terhadap kegiatan belajar berupa sebuah tindakan, yang sengaja dimunculkan dan terjadi dalam sebuah kelas secara bersama. Selanjutnya Hopkins (1993) penelitian tindakan adalah kajian sistematik dari upaya perbaikan pelaksanaan praktek pendidikan oleh sekelompok guru dengan melakukan tindakan- 
tindakan dalam pembelajaran, berdasarkan refleksi mereka mengenai hasil dari tindakan-tindakan tersebut. Sedangkan Kemmis (1983) dalam Rochiati (2005:12) menjelaskan bahwa penelitian tindakan adalah sebuah bentuk inkuiri reflektif yang dilakukan secara kemitraan mengenai situasi sosial tertentu (termasuk pendidikan) untuk meningkatkan rasionalitas dan keadilan dari 1) kegiatan praktek sosial atau pendidikan mereka, 2) pemahaman mereka terhadap kegiatan-kegiatan praktek pendidikan mereka, 3) situasi yang memungkinkan terlaksananya kegiatan praktek ini.

Rochiati (2005:13) menyebutkan bahwa penelitian tindakan kelas adalah bagaimana sekelompok guru dapat mengorganisasikan kondisi praktek pembelajaran mereka, dan belajar dari pengalaman mereka sendiri. Mereka dapat mencobakan suatu gagasan perbaikan dalam praktek pembelajaran mereka, dan dan melihat pengaruh nyata dari upaya itu. Suyanto (1997 : 4) menyatakan bahwa "PTK dapat didefinisikan sebagai suatu bentuk penelitian yang bersifat reflektif dengan melakukan tindakan-tindakan tertentu agar dapat memperbaiki dan atau meningkatkan praktek-praktek pembelajaran di kelas secara lebih profesional., karena PTK terkait erat dengan persoalan praktek pembelajaran sehari-hari yang dihadapi guru.

\section{Pentingnya Guru Melakukan PTK}

Tugas guru di sekolah memang berat, apalagi guru SD. Guru SD pada umumnya adalah guru kelas, yakni guru yang bertanggungjawab terhadap terlaksananya pembelajaran di kelas masing-masing. Selain mengajar guru kelas juga bertanggungjawab terhadap terlaksananya administrasi kelas secara keseluruhan. Meskipun tugas guru kelas berat, namun diharapkan dapat melakukan berbagai tindakan agar pembelajaran yang dilakukan senantiasa menjadi lebih baik dan praktek-praktek pembelajaran yang dilakukan di kelasnya lebih professional. Salah satu tindakan yang dapat dilakukan guru untuk mencapai hal tersebut adalah melakukan PTK.

Selain itu perlunya guru melakukan PTK menurut Hopkins dalam Wardani (2007) PTK dipandang sebagai satu unjuk kerja seorang guru yang professional, yang dilakukan terhadap diri sendiri. Dengan pengalaman melakukan PTK guru akan merasa lebih mantap berpartisipasi dalam berbagai kegiatan inovatif di sekolah.

\section{Tujuan PTK}

Tujuan PTK adalah meningkatkan dan atau perbaikan praktek pembelajaran yang seharusnya dilakukan guru. PTK merupakan salah satu cara yang stategis bagi guru untuk meningkatkan dan atau memperbaiki layanan pendidikan bagi guru dalam konteks pembelajaran di kelas. Niff (1922) dalam Suyanto (1997) menegaskan bahwa dasar utama dilaksanakannya PTK adalah untuk perbaikan.

Mulyasa (2005:155) mengatakan bahwa tujuan PTK adalah untuk:

1) Memperbaiki dan meningkatkan kondisi dan kualitas pembelajaran di kelas

2) Meningkatkan layanan profesional dalam konteks pembelajaran di kelas, khususnya layanan kepada peserta didik

3) Memberikan kesempatan kepada guru untuk melakukan tindakan dalam pembelajaran yang direncanakan di kelas, dan

4) Memberikan kesempatan kepada guru untuk melakukan pengkajian terhadap kegiatan pembelajaran yang dilakukannya.

Perbaikan pengajaran melalui PTK dapat dilakukan dengan melakukan berbagai tindakan alternatif dalam memecahkan berbagai persoalan pembelajaran di kelas. Oleh karena itu fokus penelitian tindakan terletak pada tindakan-tindakan alternatif yang direncanakan oleh guru, kemudian dicobakan, dan selanjutnya di evaluasi apakah tindakan-tindakan alternatif itu dapat digunakan untuk memecahkan persoalan pembelajaran yang sedang dihadapi oleh guru.

\section{Manfaat PTK}

Suyanto (1997) dalam Mulyasa (2005) mengemukakan manfaat PTK antara lain adalah :

a. Inovasi pembelajaran

Guru perlu selalu mencoba untuk mengubah dan mengembangkan serta meningkatkan gaya mengajarnya agar ia mampu melahirkan model pembelajaran yang sesuai dengan tuntutan 
kelasnya. Bila guru melakukan PTK di kelasnya berarti ia sudah melakukan proses inovasi pembelajaran.

b. Upaya pengembangan kurikulum di tingkat sekolah dan di tingkat kelas

Guru kelas punya tanggung jawab terhadap pengembangan kurikulum dalam level sekolah dan atau kelas. PTK akan sangat bermanfaat jika digunakan sebagai salah satu sumber masukan. Sebagaimana yang dikatakan Elliott (1992), bahwa proses reformasi kurikulum secara teoritik tidak netral, sebaliknya proses itu akan dipengaruhi oleh gagasan-gagasan yang saling berhubungan mengenai hakikat pendidikan, pengetahuan dan pengajaran. PTK dapat membantu guru untuk lebih dapat memahami hakikat tersebut secara empirik, dan bukan pemahan yang bersifat teoritik.

c. Meningkatan profesionalisme guru

Guru yang profesional tentu tidak enggan melakukan perubahan-perubahan dalam praktek pembelajaran sesuai dengan kondisi kelasnya. PTK merupakan salah satu media yang dapat digunakan guru untuk memahami apa yang terjadi di kelas, kemudian meningkatkannya ke arah perbaikan-perbaikan secara profesional. Guru yang profesional perlu melihat dan menilai sendiri secara kritis terhadap praktek pembelajarannya di kelas.

\section{Kesimpulan}

Sertifikat profesi merupakan pengakuan LPTK yang telah ditentukan atas kompetensi yang dimiliki guru. Jika guru sudah memiliki sertifikat profesi ini, berarti secara formal pemerintah mengakui eksistensi kompetensi yang dimiliki guru. Sertifikat tersebut dijadikan salah satu syarat untuk menaikkan penghasilan guru dalam jabatannya sebagai guru. Hal ini membakar motivasi guru untuk mempersiapkan bahanbahan/bukti fisik kompetensi yang dimilikinya selengkap mungkin, agar mereka memperoleh nilai sesuai dengan yang dipersyaratkan lembaga.

Salah satu bahan/bukti fisik yang dapat dimasukkan guru sebagai bahan penilaian adalah karya ilmiah. Jika guru mampu menyajikan sebagian bahan fortofolionya dalam bentuk karya ilmiah, maka besar kemungkinan batas penilaian minimal dapat dicapai oleh guru. Namun kenyataannya hanya sebagian kecil saja guru yang mampu menunjukkan kompetensinya melalui karya ilmiah. Hal ini dapat dijadikan satu indikasi bahwa guru masih minim sekali dalam menulis karya ilmiah. Barangkali hal ini dapat disebabkan beberapa faktor, seperti kurangnya waktu bagi guru untuk menulis karya ilmiah, kemampuan guru dalam menulis karya ilmiah masih kurang, dan motivasi berprestasi guru melalui karya ilmiah juga kelihatannya sangat kurang. Selain untuk memenuhi bahan sertifikasi dan naik pangkat, pengetahuan dan keterampilan melakukan penelitian tindakan kelas juga seharusnya sudah merupakan kebutuhan bagi guru. Dikatakan demikian karena melalui PTK guru dapat memperbaiki strategi pembelajaran yang dilakukan sehingga pembelajaran yang dilakukan lebih menyenangkan dan efektif.

Sebagian guru terkesan menunjukkan keinginan untuk melakukan PTK, namun terkendala dengan kemampuan yang dimiliki. Hal ini dapat dilihat dari ambisi mereka untuk bertanya, minta dibimbing, bahkan ada yang ingin bersama-sama melakukan PTK di sekolah mereka masing-masing. Namun keinginan tersebut belum pernah terealisasi, karena menurut guru belum memiliki pengetahuan dan keterampilan dalam melakukan PTK.

Salah satu usaha yang mungkin dilakukan untuk membantu guru mengembangkan profesinya melalui karya ilmiah adalah melaksanakan pelatihan Penelitian Tindakan Kelas (PTK) bagi guru-guru khususnya guru SD di Padang Timur.

Hasil Kegiatan Pengabdian masyarakat yang dilakukan UPTD Padang Timur menunjukkan bahwa guru sudah mulai memahami metode penelitian tindakan kelas, guru mampu menyusun rancangan PTK, guru mampu melaksanakan PTK. Peserta juga mampu menemukan alternative lain, kemudian dicobakan, dan selanjutnya di evaluasi apakah tindakan-tindakan alternatif itu dapat digunakan untuk memecahkan persoalan pembelajaran yang sedang dihadapi oleh guru.

Setelah mengikuti kegiatan pelatihan PTK peserta telah mendapatkan wawasan, pengetahuan, pemahaman dan ketrampilan dalam menunjang penyelenggaraan tugas sebagai guru di sekolah, kegiatan ini memberikan semangat kembali kepada para guru untuk lebih giat lagi, bahkan harapan ini dikemukakan langung oleh perwakilan dari peserta agar kegiatan serupa lebih sering untuk dilaksanakan. 


\section{Referensi}

Ifdil, I. (2010). Pendidikan Karakter dalam Bimbingan dan Konseling. Pedagogi: Jurnal Ilmu Pendidikan, 10(2), 55-61.

Rochiati, Wiraatmaja. (2005). Metode Penelitian Tindakan Kelas. Untuk meningkatkan kinerja guru dan dosen. Bandung : Kerjasama Pascasarjana UPI dan PT Remaja Rosdakarya.

Sudarsono, F.X. (1997). Pedoman Pelaksanaan Penelitian Tindakan Kelas: Bagian Kedua, Rencana, Desain dan Implementasi. Yogyakarta : UKMP SD, BP3SD.

Suharsimi Arikunto dkk (2006). Penelitian Tindakan Kelas . Jakarta.PT Bumi Aksa.

Supardi. (2004). Penelitian Tindakan Kelas: Penyusunan Proposal dan Laporan Penelitian. Jakarta : Dirjen Dikdasmen.

Suwarsih, Madya. (1994). Panduan Penelitian Tindakan . Yogyakarta : Lembaga Penelitian IKIP Yogyakarta.

Suyanto. (1997). Pedoman Pelaksanaan Penelitian Tindakan Kelas (PTK).: Bagian kesatu, PengenalanPenelitian Tindakan Kelas.. Yogyakarta UKMP SD, BP3SD. 